\title{
The Public Policy-Implementing Role of Nordic Courts in Civil Dispute Resolution
}

\author{
Clement Salung Petersen
}

\begin{abstract}
This chapter explores the role of Nordic courts in safeguarding certain public values and interests, whether substantial or procedural, in the three types of civil dispute resolution that can potentially lead to state enforcement, namely civil litigation, arbitration and mediation. First, it shows how Nordic courts in civil litigation may take on an'active role' vis-à-vis the parties but that the legal contours of this role remain unclear and controversial. Secondly, it shows how current and proposed statutory frameworks governing arbitration and mediation give national courts an important role in safeguarding public values and interests which raises important questions in law concerning the role of courts as gatekeepers of access to court and state enforcement for private actors. The chapter concludes with a discussion of the need for developing a clearer and more coherent approach to defining this public policy-implementing role of courts across all three types of civil dispute resolution. It is argued that such a coherent approach is needed and that it will be valuable to analyse the public policy-implementing role of courts in a Nordic context, since the Nordic countries generally share many of these relevant public values and interests.
\end{abstract}

\section{Introduction}

During the twentieth century, the Nordic welfare states established a clear social dimension in their laws. This significantly changed the view on the state into what we today usually refer to as the 'Nordic model', in which the state actively protects and promotes social values through economic and social policies. ${ }^{1}$ Today, both the Nordic countries and the European Union continue to use law as an important instrument to safeguard certain economic, social and political values and interests in society. Examples of such 'public values and interests' include protection of weaker parties (e.g., consumers and employees); safeguarding the functioning of markets (e.g.,

\footnotetext{
${ }^{1}$ See, e.g., J. H. Petersen (2019).
}

C. S. Petersen $(\bowtie)$

Faculty of Law, University of Copenhagen, Karen Blixens Plads 16, 2300 København, Denmark e-mail: clement.petersen@jur.ku.dk 
competition law, financial regulation, and free movement law); safeguarding thirdparty interests (e.g., company law and insolvency law); and broader public interests (e.g., combatting corruption, fraud, money laundering, etc.). ${ }^{2}$ Meanwhile, private actors have come to play a significant societal role in the Nordic countries with regard to providing goods and services of essential importance to markets and welfare. In this regard, private actors often establish and enforce private legal orders to help them operate on multi-jurisdictional markets, and such private governance of their activities may affect the public values and principles promoted by state governance. ${ }^{3}$ Because of these societal developments, disputes about civil rights and obligations may increasingly concern public values and interests such as consumer protection, workers' rights, equal treatment, fair market practices, environmental protection, social policy, and health. ${ }^{4}$

With regard to civil dispute resolution, we have seen increasing support for the use of consensual arbitration (hereinafter 'arbitration') and mediation as private and usually confidential alternatives to civil litigation in public courts. ${ }^{5}$ Recent research even suggests that arbitration (instead of civil litigation) should become the default mode of dispute resolution in transnational commercial disputes. ${ }^{6}$ Under the New York Convention on Arbitration of 1958 and the newly enacted Singapore Convention on Mediation of 2019, states and their national courts must generally recognise and enforce arbitral awards and mediated settlement agreements, even though national courts may also exercise some (limited) judicial control over the arbitration/mediation procedure and its outcome. As a result, three distinct forms of civil dispute resolution can now provide private actors with access to state-enforced civil justice-namely, civil litigation, arbitration and mediation. At the same time, state legislation requires public courts to enforce arbitration agreements and mediation agreements, respectively, by (to some extent) limiting access to civil litigation. ${ }^{7}$

These developments raise important questions concerning the role of courts as gatekeepers of access to the court and access to state enforcement in disputes about civil rights and obligations. A question of particular importance in this regard is the public policy-implementing function of courts with regard to safeguarding the fundamental procedural guarantees enshrined in ECHR Article 6 and preventing (the enforcement of) substantive outcomes that violate certain public values and interests like those mentioned above. How and to what extent shall courts in the three forms of civil dispute resolution safeguard such specific rights and obligations from state legal

\footnotetext{
${ }^{2}$ Cordero-Moss (1999) and Cordero-Moss (2018).

${ }^{3}$ On this development and its legal implications in private law and civil dispute resolution, see Hansen et al. (2020) with references.

${ }^{4}$ Hansen et al. (2020).

${ }^{5}$ On the privatisation of civil justice, see, e.g., Genn (2012) and Hess (2019).

${ }^{6}$ Cuniberti (2015).

${ }^{7}$ See, in particular, Article 8 of the UNCITRAL Model Law on International Commercial Arbitration, 1985, with amendments as adopted in 2006, and Article 14 of the UNCITRAL Model Law on International Commercial Mediation and International Settlement Agreements Resulting from Mediation, 2018, amending the Model Law on International Commercial Conciliation, 2002. See also Sect. 3.2 below.
} 
orders, whether substantive or procedural, irrespective of the will of the parties, before providing them with access to state enforcement? With the developments mentioned above, this question has become fundamentally important for understanding the role of courts and the interplay between state legal orders and private ordering in the age of globalisation. Nonetheless, legal scholarship traditionally analyses the public policyimplementing role of courts in arbitration separately from the similar role of courts in civil litigation. With the newly enacted Singapore Convention on Mediation, similar questions will potentially arise in the Nordic countries (if they adopt the convention) with regard to mediation.

Against this background, the aim of this chapter is to explore how the abovementioned developments affect the role of Danish, Norwegian and Swedish courts in safeguarding public values and interests, whether substantial or procedural, in the three types of civil dispute resolution that can potentially lead to state enforcementnamely, civil litigation, arbitration and mediation. First, it will show how courts in civil litigation in Denmark, Norway and Sweden increasingly may take on an 'active role' vis-à-vis the parties but that the legal contours of this role remain unclear and controversial. Secondly, it will show how current and proposed statutory frameworks governing arbitration and mediation (as distinct alternatives to civil litigation) give national courts an important role in safeguarding public values and interests, and that this role raises important questions in law concerning the role of courts as gatekeepers of access to court and state enforcement for private actors. Thirdly, it will discuss the need for developing a clearer and more coherent approach to defining the public policy-implementing role of courts across all three types of civil dispute resolution, including the potential benefits of doing so in a Nordic context. Because of language barriers, the analysis will not include Finnish and Icelandic law but focus on Danish, Norwegian and Swedish law. All references to 'Nordic' in the analyses will thus refer to these three Nordic jurisdictions, unless otherwise explicitly stated.

\section{Civil Litigation}

\subsection{Role of Courts}

Party autonomy is a fundamental value in the modern Nordic laws on civil procedure. ${ }^{8}$ The courts shall only adjudicate a dispute if requested by a party, and it is generally for the parties to define their legal dispute and adduce relevant evidence. In dispositive civil disputes, courts shall traditionally be passive and not seek to influence the choices of the parties with regard to their claims, allegations and evidence. This passive role of courts in civil procedure reflects a mid- $19^{\text {th }}$-century liberalist view on the state and, in this sense, represents a 'liberal procedural ideology'.

\footnotetext{
${ }^{8}$ Petersen (2014) with references.

${ }^{9}$ See, e.g., Westberg (1988), p. 33, and van Rhee (2005), p. 11.
} 
As mentioned, civil disputes increasingly concern matters governed by statutory law in which the welfare state seeks to promote certain public values or interests. ${ }^{10}$ This active role of the Nordic welfare states as regulators has challenged the liberal procedural ideology governing the state as adjudicator (through its state courts). State courts in civil litigation can thus (potentially) play an important, active role in safeguarding public values and interests promoted by the state (as strongly emphasised by Franz Klein in his seminal work Pro Futuro (1891)). ${ }^{11}$ With the development of the Nordic welfare states, it is therefore not surprising that exceptions to the traditionally passive role of courts have also gradually emerged in the Nordic countries. ${ }^{12}$ Significant examples of such court activity include investigating issues of fact or law ex officio, providing judicial guidance or giving hints and feedback to the parties, ex officio ordering a self-represented party to take on legal representation, and promotion of settlement.

The aim of the following analysis is to explore the public policy-implementing role of courts - that is, how courts take an active role in civil litigation to safeguard public values and interests. The analysis will comprise the adjudicatory role of courts (Sect. 2.2), the settlement-promoting role of courts (Sect. 2.3) and the role of courts in court-connected mediation (Sect. 2.4, which also defines the concept of courtconnected mediation).

\subsection{Court Adjudication}

\subsubsection{Jura Novit Curia}

When analysing the public policy-implementing role of court adjudication in the Nordic countries, the starting point is the principle usually referred to as iura novit curia, which means that courts have an ex officio obligation to identify and apply the relevant law correctly regardless of the legal arguments of the parties. This principle will often allow Nordic courts to apply relevant statutory law that seeks to promote public values and interests. However, under the principle of party presentation courts generally cannot go beyond the ambit of the dispute as defined by the parties in their claims and allegations. This can create tension if the parties rely on statements of fact that do not allow the court to address aspects of the dispute that concern public values or interests. Parties may have an interest in disregarding such aspects of the dispute, so the ability of a court to give hints and feedback to the parties concerning such an issue might not be sufficient to convince the parties to establish a factual basis for doing so. In this context, the pertinent question is whether courts can or must raise and consider issues of fact ex officio, if none of the parties has explicitly relied upon them, when the facts are necessary to consider aspects of the dispute that

\footnotetext{
${ }^{10}$ See examples mentioned in Sect. 1 above.

${ }^{11}$ See van Rhee (2005), pp. 11-13.

${ }^{12}$ See, in particular, Taksøe-Jensen (1979), Westberg (1988) and Eldjarn (2016).
} 
concern public values or interests. Furthermore, Nordic courts might be unable to apply statutory law because of conflict-of-law rules.

To understand the public policy-implementing role of Nordic court adjudication in further detail, it becomes relevant to distinguish between different types of legal rules. More specifically, the analysis will distinguish between the fundamental legal principles and values in the state legal order typically referred to as public policy (ordre public) in private international law and international procedural law ${ }^{13}$ (2.2.2), mandatory protection rules (2.2.3) and other rules (2.2.4).

\subsubsection{Safeguarding Public Policy (Ordre Public)}

If relevant for safeguarding rules of public policy (ordre public) in civil litigation, Nordic courts may set aside the principle of party presentation. Danish and Norwegian civil procedure law provides statutory support for this. ${ }^{14}$ In Swedish civil procedure law, courts may also rely on certain facts ex officio in dispositive civil disputes (so-called officialfakta) despite the lack of clear statutory support for this in the Swedish Judicial Code. ${ }^{15}$ Illustrative examples from Danish case law concern claims for specific performance of contractual obligations which involve a criminal offense, as well as the collection of debt originating from undeclared work (moonlighting) or bribes. ${ }^{16}$ An illustrative example from Swedish case law concerns ex officio enforcement of public law requirements concerning acquisition of certain types of property. ${ }^{17}$

In recent decades, Danish courts seem to have increasingly used this ex officio power to safeguard public policy in civil litigation. This has raised the difficult question to what extent public policy concerns should bring courts to take action ex officio. As an example, courts must decide whether the fact that a service provider has offered his services as undeclared work affects only a claim for payment for the services or any claim based on such contract, including remedies for the service provider's breach of contract. In the latter case, public policy concerns might leave people in private law relationships without legal protection under the rule of law. Some commentators have criticised the Danish courts for going too far in this regard. ${ }^{18}$ The aim here is not to go into a thorough analysis of these questions but merely to show that an active public policy-implementing role of courts raises legal questions that are unclear and also quite controversial.

\footnotetext{
${ }^{13}$ See, e.g., Hess and Pfeiffer (2011).

${ }^{14}$ See Sect. 338 in the Danish Administration of Justice Act (which allows Danish courts to also rely on 'allegations that the parties cannot waive') and Sect. 11-4 in the Norwegian Civil Dispute Act.

${ }^{15}$ See Westberg (1988), p. 83, and Ekelöf and Edelstam (2002), pp. 64-65.

${ }^{16}$ Petersen (2019), p. 495.

${ }^{17}$ See Ekelöf and Edelstam (2002), pp. 64-65.

${ }^{18}$ See Tromborg (2015), Faldborg and Troelsen (2016).
} 
Where domestic law allows ex officio application of rules of public policy, it is for the national court to apply any applicable fundamental rules of EU law, such as the antitrust provisions in the Treaty on the Functioning of the European Union. ${ }^{19}$ In general, EU law does not require national courts 'to abandon the passive role assigned to them by going beyond the ambit of the dispute defined by the parties themselves and relying on facts and circumstances other than those on which the party with an interest in application of those provisions bases his claim' ${ }^{20}$ However, when Nordic courts (as discussed above) may rely on other facts ex officio to safeguard domestic public policy, a similar obligation will apply with regard to EU public policy under the principle of equivalence. ${ }^{21}$

\subsubsection{Safeguarding Mandatory Statutory Protection}

Both the Nordic welfare states and the EU have enacted mandatory statutory laws that aim to protect so-called 'weaker parties' such as consumers and employees. Some of these mandatory rules are 'absolute' and thus have the same character as the fundamental rules of public order discussed above. Other statutory protection rules allow the weaker party to waive the protection ex ante (after the rise of a dispute). These rules can also raise difficult questions about the role of courts in civil litigation, which I will illustrate below by focusing on two distinct procedural situations in which such questions may arise.

The first situation arises when a weaker party appearing before a court in a civil litigation omits arguments concerning the relevant mandatory statutory protection laws. This omission may be due to a deliberate choice made by the weaker party to waive the statutory protection, but it may also be due to a lack of awareness of his/her rights under the applicable statutory law. As mentioned, courts generally have an obligation to identify and apply the relevant law correctly regardless of the legal arguments of the parties (iura novit curia), but courts must respect the principle of party presentation and thus cannot go beyond the factual ambit of the dispute as defined by the parties (see supra 2.2.1). Unlike the rules of public order discussed in Sect. 2.2.2, Danish, Nordic and Swedish courts have no general power to ex officio include facts not relied upon by the parties in order to make mandatory statutory protection rules applicable. ${ }^{22}$ Instead, the court may provide judicial guidance or give hints and feedback to the weaker party about the potential relevance of the mandatory rules. If the weaker party is self-represented, in some situations the court can also order the weaker party to take legal representation. Danish, Norwegian and Swedish courts only have a duty to take on such an active role in dispositive disputes in

\footnotetext{
${ }^{19}$ This follows from the so-called principle of equivalence developed in the CJEU case law; see, e.g., Lenaerts et al. (2014), p. 118.

${ }^{20}$ See Van Schijndel, ECLI:EU:C:1995:441.

${ }^{21}$ See e.g. Lenaerts et al. (2014), p. 118.

${ }^{22}$ This follows from Sect. 338 of the Danish Administration of Justice Act, Sect. 11 of the Norwegian Dispute Act and Sect. 17:3 of the Swedish Judicial Code.
} 
a few specific circumstances. In particular, Nordic courts often have a duty to provide judicial guidance to self-represented parties. In Danish law, this follows explicitly from Sect. 339(4) of the Danish Administration of Justice Act. A similar duty exists without explicit statutory support under Norwegian law and Swedish law. ${ }^{23}$ In other cases, Danish, Norwegian and Swedish courts have no duty but generally a wide discretion to provide judicial hints and feedback to the parties. There seems to be no clear guidelines in these countries concerning when courts should exercise this discretion to safeguard mandatory statutory protection laws.

Danish courts have a wide discretion to take on the active role described above under Sect. 339(1)-(3) and Sect. 259(2) of the Danish Administration of Justice Act. In 2001, the Danish Administration of Justice Committee discussed the need for clearer rules about the role of Danish courts with regard to providing judicial hints and feedback to safeguard mandatory statutory protection laws. The committee concluded that it would return to this pertinent question in the future. ${ }^{24}$ As of 2019 , the committee still has not addressed this question, and it remains unclear whether Danish courts should generally exercise their discretion to give hints and feedback to safeguard mandatory statutory protection laws.

Norwegian courts also have a wide discretion to provide judicial hints and feedback to the parties in dispositive civil disputes under Sect. 11-5 of the Norwegian Dispute Act. According to the preparatory works to the Norwegian Dispute Act, courts should follow some of the principles that are applicable in non-dispositive civil disputes in dispositive civil disputes as well (e.g., to provide hints and feedback in cases involving a weaker party vis-a-vis a strong party). ${ }^{25}$ The scope of any such duty, including a duty to provide judicial hints and feedback to ensure that a weaker party is aware of his/her rights under mandatory statutory laws, generally remains unclear. $^{26}$

Swedish courts also have discretion to provide judicial hints and feedback under Sects. 42:8 and 43:4 of the Swedish Judicial Code. In connection with a significant reform of these rules, an expert committee addressed the implications of potentially relevant mandatory statutory protection laws in dispositive civil disputes. ${ }^{27}$ According to the majority view in the committee, mandatory statutory protection laws should not lead to a more active role of courts in dispositive civil disputes, whereas three members of the committee argued that if such laws could be potentially relevant courts should take on a more active role in their safeguarding. ${ }^{28}$ The subsequent bill that implemented the law reform left this question quite open. ${ }^{29}$ Today, the scope of any duty of courts to provide hints and feedback remains unclear. ${ }^{30}$

\footnotetext{
${ }^{23}$ See Skoghøy (2017), p. 966, and Lindell (2012), p. 295.

${ }^{24}$ Retsplejerådet (2001) Betænkning 1401 om Reform af den civile retspleje I, p. 315.

${ }^{25}$ Ot.prp. no. 51 (2004-2005) p. 177.

${ }^{26}$ See Eldjarn (2017), pp. 210-212 with references.

${ }^{27}$ SOU 1982:26.

${ }^{28}$ SOU 1982:26, pp. 114, 609, 610 and 616.

${ }^{29}$ Prop 1986/87:89, p. 106, and Westberg (1988), p. 619.

${ }^{30}$ Ekelöf and Edelstam (2002), p. 45; Westberg (2012), p. 330; and Lindell (2012), p. 293.
} 
A second situation arises when courts render a default judgment. Do courts have a duty to enforce (potentially) applicable mandatory statutory protection laws, or is it justifiable to assume that the lack of response from the defendant (as the protected weaker party) constitutes an ex post waiver of the statutory protection? Courts may enforce such rules by applying them ex officio. However, in some cases it might not be entirely clear that such laws apply, or their application might require the court to rely on facts or circumstances not put forward by the plaintiff. Should courts in such situations have an obligation to start an ex officio investigation of the relevant facts (to clarify whether the mandatory rule applies)? Alternatively, the court could provide judicial guidance to the defendant about (the possible relevance of) the mandatory statutory protection rule.

Courts in Denmark, Norway and Sweden can render a default judgment without making a full inquiry on the factual and legal basis for the claims put forward by the plaintiff. A Danish court must ascertain that the plaintiff's claim is justified based on the statement of claim and any other information available to the court. ${ }^{31}$ A Norwegian court must ascertain that the plaintiff's claim does not appear to be obviously incorrect ('åpenbart uriktig’). ${ }^{32}$ These rules on default judgments explicitly address whether the court should seek to safeguard mandatory statutory protection laws.

In Denmark, the development of consumer protection laws in the 1970's led to a call for more active courts in safeguarding consumer rights, and in the early 1980's, Danish courts appeared to be open for undertaking a more active role. ${ }^{33}$ However, recent research shows that it is difficult to find a consistent approach in Danish case law to such a more active role and that the Danish high courts have actually limited the district courts from undertaking such a role when rendering default judgments. ${ }^{34}$ Currently, it remains unclear to what extent Danish courts actively seek to safeguard statutory mandatory protection laws in connection with default judgments. ${ }^{35}$

The CJEU has taken a more extensive approach to ensuring the effectiveness of EU law on protection of consumers against unfair contractual terms, which 'are not binding on the consumer'. Thus, the CJEU has developed a number of exofficio obligations of national courts to safeguard the mandatory statutory protections against unfair contractual terms. ${ }^{36}$ Under this case law, a national court is required to assess of its own motion whether a contractual term falling within the scope of EU consumer protection law is unfair. A national court has an obligation to examine this issue of its own motion, when it has available to it the legal and factual elements necessary for the task. Generally, these ex officio obligations in EU consumer law also apply in connection with default judgments. However, the scope of these ex officio obligations

\footnotetext{
${ }^{31}$ See Sects. 352 and 360 of the Danish Administration of Justice Act.

${ }^{32}$ See Sect. 16-10(2) of the Norwegian Civil Dispute Act.

${ }^{33}$ Zahle (1983), Rosenmeier (1984).

${ }^{34}$ Christensen (2008).

${ }^{35}$ C. S. Petersen (2019).

${ }^{36}$ For an overview, see, e.g., Trstenjak (2013); Lenaerts et al. (2011), pp. 131-136; and Hess and Law (2019), pp. 111-129.
} 
of national courts is also quite unclear, and it is doubtful whether national courts live up to their obligations under EU law in this regard. ${ }^{37}$

\subsubsection{Safeguarding Other Rules of Law}

The 'liberal procedural ideology' with (generally) passive courts empowers the parties to take care of their own interests. Parties may not always be able to do this in a way that will ensure their legal rights under the rule of law. This makes it pertinent to consider whether courts should have certain duties to safeguard legal rights under the rule of law beyond the scope of rules of public policy and mandatory statutory protection laws (discussed above). As an example, German judges have quite extensive responsibilities to undertake a certain amount of positive activity during civil proceedings in the interest of ensuring a fair and just outcome. ${ }^{38}$

As mentioned in Sect. 2.2.3 above, Danish, Norwegian and Swedish courts generally have a duty to provide judicial guidance to self-represented parties in dispositive civil disputes. When a party has legal representation, these Nordic courts have a quite wide discretion to provide hints and feedback. Even though legal scholarship has developed some general guidelines for whether or not to exercise this discretion, it generally remains a controversial question whether and to what extent Nordic courts should provide judicial hints and feedback with an aim to safeguard civil justice under the rule of law. ${ }^{39}$

\subsection{Court Promotion of Settlement}

Promoting settlement is an important role of Nordic courts in civil litigation, particularly before or during first instance proceedings. Generally, Nordic courts have significant discretion with regard to whether, when and how they will promote settlement in civil litigation. ${ }^{40}$

Promoting settlement clearly supports the dispute resolution function of courts. In contrast, its relationship with the other functions of courts in civil litigation, particularly the need of society to have its laws respected and clarified, is less clear. ${ }^{41}$ It seems clear that a Nordic court should not promote a settlement which will clearly

\footnotetext{
${ }^{37}$ See the comprehensive analysis in Hess and Law (2019).

${ }^{38}$ See Murray and Stürner (2004), p. 155 and pp. 166-177.

${ }^{39}$ On Danish law, see C. S. Petersen (2019) with references. On Norwegian law, see Skoghøy (2017) and Eldjarn (2016), both with references. On Swedish law, see Westberg (1988) and Lindell (2012), both with references.

${ }^{40}$ See, e.g., Bang-Pedersen et al. (2017), pp. 108-111; Skoghøy (2017); and Lindell (2012), pp. 303310 .

${ }^{41}$ For a comparative overview of the functions of Nordic courts in civil litigation, see Petersen (2014) with references.
} 
violate the public order (ordre public), including mandatory provisions from which the parties cannot derogate by agreement. ${ }^{42}$

In other situations, courts appear to have wide discretion to promote settlement without having regard to the rules of law. Swedish law traditionally subscribed to the view that the estimated outcome of the dispute under the rule of law (which can be subject to significant uncertainty at an early stage of the proceedings) should guide the promotion of settlement by courts. In recent decades, this view on the role of courts in civil litigation has changed, such that courts should generally promote settlement if doing so meets the interests and needs of the parties. ${ }^{43}$ This change clearly favours the dispute resolution function of courts. With regard to Norwegian law, Skoghøy argues that a legally correct decision should be the guiding star ('ledetråd') for the promotion of settlement by courts. ${ }^{44}$ However, it is not a role of Norwegian courts to control whether a party, by entering into a settlement, waives mandatory statutory protection laws, which a party is entitled to waive in a civil litigation. ${ }^{45}$ With regard to Danish law, empirical research shows that there is no clear view on this matter amongst Danish judges. ${ }^{46}$ In recent years, the Danish Ministry of Justice and the Danish Court Administration have asked consultancy firms to analyse Danish civil litigation. The consultancy reports suggest using the number of settled civil cases as an important benchmark, and they refer to the courts with the statistically highest number of settled cases as 'best practice' ${ }^{47}$ These consultancy reports reflect a view that the primary (or perhaps only) function of the Danish civil justice system is (or should be) dispute resolution.

\subsection{Court-Connected Mediation}

Court-connected mediation ${ }^{48}$ is now part of the civil justice systems in Denmark, Norway and Sweden. Based on a facilitative mediation model, court-connected mediation focuses, in particular, on the needs and interests of the parties, not on rights

\footnotetext{
${ }^{42}$ On Norwegian law in this regard, see NOU 2001:32, pp. 725-726, and Skoghøy (2017), p. 33.

${ }^{43}$ Lindell (2012), pp. 307-309.

${ }^{44}$ Skoghøy (2017), p. 33.

${ }^{45}$ Schei et al. (2009), p. 829, and NOU 2001:32, pp. 725-726.

${ }^{46}$ Adrian et al. (2015).

${ }^{47}$ Deloitte (2013), Implement Consulting Group (2015).

${ }^{48}$ Adrian (2016), p. 213 , provides the following general description of court-connected mediation in a Nordic context: 'Court-connected mediation is a voluntary settlement activity conducted by one or more neutral third parties who assist the parties in reaching their own solution in a pending court case. The court is engaged in the mediation-an engagement that can range from minimally providing a controlled list of mediators to which the parties can be referred to a full in-house service. The service is to some extend regulated by law, decrees, ethical guidelines, court rules or similar instruments. Mediation can take place at any point in time after the case is filed and before the final ruling.'
} 
and obligations under the rule of law. ${ }^{49}$ However, in this context, courts can also play an important public policy-implementing role by controlling that a settlement agreement does not violate rules of public policy (ordre public). Norwegian law generally does not require courts to safeguard mandatory statutory protection, which a party can waive by agreement. ${ }^{50}$ In court-connected mediation under Danish law, the mediator must terminate the mediation if it is necessary to do so to prevent the parties from entering during the mediation into an agreement that involves a criminal activity or in any other way contravenes mandatory law. ${ }^{51}$

Against this background, the public policy-implementing role of courts in courtconnected mediation appears to be limited to ensuring that courts do not support agreements that will violate public policy (ordre public), including mandatory provisions from which the parties cannot derogate by agreement.

\subsection{Reflections}

The analyses above show how the public policy-implementing role of Nordic courts in civil litigation is in several respects unclear and in some respects also controversial. As a general observation, Nordic courts appear to have a quite wide discretion, but only few duties, to take on a public policy-implementing role. In particular, it remains unclear to what extent courts should exercise their discretion to safeguard mandatory statutory protection laws or even legal rights in general. Views differ, presumably reflecting different political views on the role of the state vis-a-vis private autonomy, and the law generally leaves it to the discretion of judges in the individual case to decide the extent of their public policy-implementing role.

The analyses also show how EU law has created more explicit and potentially more far-reaching exofficio obligations, particularly in EU consumer law. Even though these obligations are also subject to significant uncertainty, they lead to a fragmented civil justice system in the Nordic countries, since the public policy-implementing role of courts will differ depending on whether or not the disputes concern matters regulated by EU law.

\footnotetext{
${ }^{49}$ For an overview, see,e.g., Nylund et al. (2018).

${ }^{50}$ See Sect. 19-11(3) of the Norwegian Dispute Act and Schei (2009), p. 829, with references.

${ }^{51}$ See Sect. 276(2) of the Danish Administration of Justice Act.
} 


\section{Arbitration and Mediation}

\subsection{Role of Courts}

The Nordic countries generally support consensual arbitration as an alternative to civil litigation in commercial disputes. The UNCITRAL Model Law on Commercial Arbitration (Model Law) constitutes the basis for the Danish Arbitration Act (DAA) and the Norwegian Arbitration Act (NAA), whereas the Swedish Arbitration Act (SAA) has a different form but still generally follows the Model Law in substance. ${ }^{52}$ All three Nordic countries have adopted the New York Convention on Arbitration of 1958.

Mediation, as a separate form of dispute resolution unconnected to court litigation, has only more recently attracted the interest of legislators. The EU has adopted Directive 2008/52/EC on certain aspects of mediation in civil and commercial matters, which is binding neither on Denmark (Article 1(3) and Recital 30 of the Directive) nor on Norway (no EEA relevance). The Swedish Act No 2011:860 transposes this Directive into Swedish law. The Norwegian Dispute Act includes some rules on extra-judicial mediation (see Chapter 7 of the Act). Denmark has not adopted any similar legislation.

Important legal frameworks for mediation are now emerging at the international level, including the UNCITRAL Model Law on International Commercial Mediation 2018 and the newly enacted Singapore Convention 2019. Against this background, a recent report from an expert committee established by the Danish Arbitration Institute has drafted a proposal for a new Danish Mediation Act. ${ }^{53}$

The aim of the following analysis is to explore the potential public policyimplementing role of courts in disputes, which the parties submit to consensual arbitration or mediation as an alternative to civil litigation. Specifically, the aim is to explore to what extent national courts can safeguard public values and interests in such arbitration or mediation. The analysis will comprise the legal implications of arbitration and mediation agreements as waivers of the right of access to a court (Sect. 3.2), the role of courts during a pending arbitration or mediation (Sect. 3.3), court control of arbitral awards (Sect. 3.4) and court control of mediated settlements (Sect. 3.5).

\footnotetext{
${ }^{52}$ See, e.g., Juul and Thommesen (2017) on Danish law, Woxholth (2013) on Norwegian law, and Lindskog (2012) on Swedish law.

${ }^{53}$ See Voldgiftsinstituttet (2018).
} 


\subsection{Waiver of the Right of Access to a Court}

\subsubsection{Arbitration}

It is a fundamental feature of modern arbitration laws based on the Model Law that when an action is brought before a national court in a matter that is the subject of an arbitration agreement, the court shall refer the parties to arbitration, unless the court finds that the arbitration agreement is null and void, inoperative or incapable of being performed. Thus, an arbitration agreement generally constitutes a waiver of the right of access to a court under the rule of law. Under the case law from the European Court of Human Rights (ECtHR), persons may waive their right to a court under Article 6 of the ECHR in favour of arbitration. The waiver must be permissible, must be established freely and unequivocally and must be attended by minimum safeguards commensurate to its importance. ${ }^{54}$

The above-mentioned principle that courts should normally refer parties to arbitration applies in the Nordic countries. ${ }^{55}$ It is, however, subject to certain restrictions. Only disputes concerning legal relationships with respect to which the parties have an unrestricted right of disposition may be submitted to arbitration (sometimes referred to as the requirement of 'arbitrability'. If a dispute involves issues that concern public policy, it may not be 'arbitrable'. ${ }^{56}$ Further restrictions can apply in specific types of disputes, most notably consumer law disputes. ${ }^{57}$

A judgment from the Danish Supreme Court provides an illustrative example of how the public interest may affect 'arbitrability'. ${ }^{58}$ The dispute arose between the Association of Danish Pharmacies, which is the employer and professional organisation of the pharmacies in Denmark, and one of its members. The dispute was formally about an alleged violation by the member of a rule in the bylaws of the association, but this rule mirrored a Danish statutory rule, which concerned the pricing of drugs for sale on the Danish market. This statutory rule was part of the general public law regulation of pharmacies in Denmark. In accordance with the bylaws of the association, the association submitted the dispute to arbitration and the arbitral tribunal rendered an arbitral award stating that the member had violated the bylaws and therefore should pay a 'fine' to the association. The member started a court action for setting aside this arbitral award, which was eventually heard by the Danish Supreme Court. The Supreme Court stated that the parties could not submit this kind of dispute to arbitration, because it concerned an alleged violation of a

\footnotetext{
${ }^{54}$ For an overview of this case law, see Council of Europe/European Court of Human Rights (2019) Guide on Article 6 of the European Convention on Human Rights. Right to a fair trial (civil limb). Updated to 31 August 2019. Council of Europe, p. 31.

${ }^{55}$ See DAA Sect. 8, NAA Sect. 6, and SAA Sect. 4.

${ }^{56}$ For a general discussion of this matter, see, e.g., Werlauff (2008); Werlauff (2009); SOU 1994:81, pp. 172-174; and Cordero-Moss (2018).

${ }^{57}$ See DAA Sect. 7(2), NAA Sect. 11, SAA Sect. 6.

${ }^{58}$ See judgment from the Danish Supreme Court of 17 February 1999, reported in the Danish Weekly Law Reports as U $1999.829 \mathrm{H}$.
} 
public law rule, which in essence was aiming to safeguard general public interests. The Supreme Court therefore set aside the arbitral award.

When national courts deny access to a court and instead refer a party to arbitration, they support arbitration as an alternative to court litigation. However, as the analysis above shows, courts can still control whether the dispute is capable of settlement by arbitration and, if not, provide full access to the court despite the arbitration agreement. Since the restrictions on access to arbitration reflect important public values and interests, this control constitutes an important public policy-implementing role of courts vis-à-vis arbitration as an alternative to court litigation.

\subsubsection{Mediation}

In the same vein, courts may have to consider whether they shall deny access to the court upon request from a party who wants to mediate the dispute under the terms of an agreement to mediate. This is a challenging question, since mediation is a consensual process that supports the autonomy of the disputing parties to make their own decisions about the dispute. If after a dispute arises, a party is determined not to mediate, one could argue that a general mediation agreement is unenforceable (as an 'agreement to agree' or an 'agreement to negotiate in good faith') ${ }^{59}$ However, more detailed mediation agreements, requiring parties not to initiate judicial or arbitral proceedings during a specified period or until a specified event has occurred, might provide courts with a basis for at least suspending a civil litigation. ${ }^{60}$ Article 14 of the UNCITRAL Model Law on Commercial Mediation takes steps in this direction, as do the new Danish General Conditions for the provision of works and supplies within building and engineering (the 'AB System'). ${ }^{61}$

Eventually, however, courts cannot deny access to the court because of a mediation agreement, since mediation against the will of a party is a contradictio in adjecto. In this respect, courts therefore cannot support mediation as a means of dispute resolution to the same extent as arbitration.

\footnotetext{
${ }^{59}$ Case law from common law jurisdictions has previously followed this line of argumentation. For an overview of relevant case law, see Brooker (2013), pp 42-82.

${ }^{60}$ See Hansen et al. (2020) with references.

${ }^{61}$ This new 'AB System' introduces a multi-tiered dispute resolution system, which can include different types of mediation. For details, see https://www.byggerietsregler.dk/.
} 


\subsection{Role of Courts during Arbitration and Mediation}

\subsubsection{Arbitration}

Nordic courts can support a pending arbitration in several ways. They can assist in the appointment of arbitrators. ${ }^{62}$ They can also assist in the collection of evidence, which can be a prerequisite for summoning a witness against his/her will and for the effective production of documents under applicable disclosure rules. ${ }^{63}$ Moreover, arbitral tribunals with a seat in Denmark can request that a Danish court make a preliminary reference to the CJEU. ${ }^{64}$ In the same vein, an arbitral tribunal with a seat in Norway can request that a Norwegian court make a preliminary reference to the EFTA Court. $^{65}$

Even though an arbitration agreement generally constitutes a waiver of the right of access to a court for resolving the specific dispute, Nordic courts can still play a role in controlling certain aspects of a pending arbitration upon request of a party. Most importantly, national courts can control the competence of the arbitral tribunal, including whether the dispute is capable of settlement by arbitration. ${ }^{66}$ Courts can also control the impartiality and independence of arbitrators ${ }^{67}$ and the costs of the arbitral tribunal. ${ }^{68}$

The above-mentioned rules enable national courts to safeguard certain fundamental aspects of due process in arbitration, including those institutional and procedural requirements of Article 6 ECHR that the parties have not waived by entering into an arbitration agreement. ${ }^{69}$

\subsubsection{Mediation}

The focus here is on mediation used as an alternative to civil litigation. Since mediation is a consensual dispute resolution process, court control of a pending mediation process does not play the same role as in arbitration (as discussed above). However, the legislative frameworks on mediation (such as those discussed above) can empower the courts to control the costs of the mediator(s). ${ }^{70}$

\footnotetext{
${ }^{62}$ See DAA Sect. 11, NAA Sect. 13, and SAA Sects. 12 and 14-17.

${ }^{63}$ See DAA Sect. 27(1), NAA Sect. 30(1) and SAA Sect. 26.

${ }^{64}$ See DAA Sect. 27(2).

${ }^{65}$ See NAA Sect. $30(2)$.

${ }^{66}$ See DAA Sect. 16, NAA Sect. 18, SAA Sect. 2.

${ }^{67}$ See DAA Sect. 13, NAA Sect. 15, SAA Sect. 10.

${ }^{68}$ See DAA Sect. 34, NAA Sect. 39, SAA Sect. 41.

${ }^{69}$ On the applicability of ECHR Article 6 to arbitration, see, e.g., Jaksic (2002), Jaksic (2007) and Krumins (2019).

${ }^{70}$ Section $7-4$ of the Norwegian Dispute Act and Sect. 18 of the proposal for a Danish Mediation Act.
} 
Courts may support mediation in ways comparable to the way courts can support arbitration. Courts may assist in the appointment of mediators. ${ }^{71}$ They may also support mediation by enforcing confidentiality obligations (e.g., in connection with restrictions on admissibility of evidence in subsequent civil litigation). ${ }^{72}$

\subsection{Court Control of ADR Outcomes}

\subsubsection{Arbitral Awards}

When an arbitral tribunal has rendered an arbitral award, the courts shall generally recognise that award as binding and enforceable. However, a court may subsequently control certain aspects of the arbitral award in setting aside proceedings, provided the arbitration took place within the jurisdiction of the court or in proceedings concerning recognition and enforcement of the award. ${ }^{73}$ These provisions in the three Nordic arbitration acts include an exhaustive list of grounds for setting aside or refusing recognition and enforcement of arbitral awards, which are identical to or largely correspond to those in the UNCITRAL Model Law, which again largely reflect those in the New York Convention. These grounds include certain serious violations of due process or other procedural irregularities and an excess of power by the arbitral tribunal (ne ultra petita). ${ }^{74}$

Furthermore, the legislative frameworks allow some limited control by national courts of the substantive outcome in arbitral awards, which courts can use to safeguard certain public values and interests. First, courts can control (ex officio, if necessary) whether the arbitral award is contrary to public policy (ordre public). Public policy also comprises fundamental principles of EU law such as the previously mentioned antitrust rules in the Treaty on the Functioning of the European Union. ${ }^{75}$ Second, courts can control (ex officio, if necessary) that the dispute was capable of settlement by arbitration. This includes the fundamental requirement that disputes must concern legal relationships with respect to which the parties have an unrestricted right of disposition. In the Nordic countries, this notably includes the explicit consumer protection restrictions mentioned in Sect. 3.2.1 above. These grounds enable national courts to safeguard the 'strongest' public values and interests such as those discussed in Sect. 2.2.2 above.

\footnotetext{
${ }^{71}$ See e.g. Section 7-2 of the Norwegian Civil Dispute Act and Sect. 7 of the proposal for a Danish Mediation Act.

${ }^{72}$ See, e.g., Sect. 7-3(6) of the Norwegian Civil Dispute Act, Sect. 5 of the Swedish Mediation Act, Sect. 15 of the proposal for a Danish Mediation Act, and Article 7 of the Mediation Directive.

${ }^{73}$ For details, see DAA Sect. 37-39, NAA Sects. 42-47 and SAA Sects. 33-36.

${ }^{74}$ Ibid.

${ }^{75}$ Eco Swiss, ECLI:EU:C:1999:269.
} 
With regard to mandatory statutory protection laws and other rules of law (as discussed in Sects. 2.2.2, 2.2.3 above), national courts generally have no competence to control whether the arbitral tribunal has applied such law correctly. Nordic arbitration laws do not impose any duty on arbitrators to provide guidance or to give hints and feedback to the parties in an arbitration.

In conclusion, Nordic courts can generally safeguard public values and interests only if they are inherent in fundamental rules of public policy (ordre public) or in matters excluded as 'not capable of settlement by arbitration under the Nordic arbitration laws.

\subsubsection{Mediated Settlements}

Even when the parties have chosen to mediate and have reached a settlement, courts can generally control the binding effect and validity of such a mediated settlement. However, under the newly enacted Singapore Convention, certain mediated settlement agreements (agreements resulting from mediation and concluded in writing by parties to resolve a commercial dispute) shall generally become directly enforceable under the conditions laid down in the Convention. The Convention includes an exhaustive list of grounds for refusing to grant relief to enforce a settlement agreement (see Article 5 of the Convention), which largely resembles the regulation known from the New York Convention on Arbitration (mentioned in Sect. 3.1 above). The Convention will thus generally enable national courts to safeguard public values and interests to the same (limited) extent as in arbitration (as described in Sect. 3.4.1 above). The grounds in the Convention for refusing to grant relief also address some special issues arising in mediation, including the potential implications of a mediator having unduly influenced the parties' decision to enter into the settlement agreement. These grounds will enable national courts to safeguard certain fundamental due process principles in mediation.

\subsection{Reflections}

The analyses show that national courts can play an important role in safeguarding public values and interests in both arbitration and mediation. Courts shall perform this role within the applicable statutory frameworks, which currently provide courts with some instruments to control arbitration and mediation, both with regard to preventing enforcement of arbitral awards or settlements that are contrary to certain public values and interests and with regard to safeguarding certain (minimum) procedural guarantees in arbitration and mediation.

Under the current statutory frameworks, the scope of this role of national courts will depend, in particular, on the scope of the grounds for setting aside, or for refusing recognition and enforcement of, arbitral awards and the ground for refusing to grant relief based on a mediated settlement agreement. Apart from the specific procedural 
guarantees offered by these frameworks, the public policy-implementing role of courts will depend on national laws regarding when the 'subject matter of the dispute is not capable of settlement by' arbitration or mediation and the legal concept of public order (ordre public). Both of these legal concepts are today subject to significant legal uncertainty, but they both enable courts to limit access to state enforcement if necessary to avoid a violation of certain (strong) public values and interests.

\section{The Public Policy-Implementing Role of Nordic Courts}

This chapter has explored the public policy-implementing role of Nordic courts in civil litigation, arbitration and mediation. It generally shows that courts can play an important role in safeguarding public values and interests in a broad sense, whether procedural or substantial, in all three types of civil dispute resolution, but to varying degrees.

The analyses show that Nordic courts have an important role in safeguarding due process. In civil litigation, this role of courts is subject to detailed regulation, including the requirement of ECHR Article 6. In arbitration, national courts can play a role in safeguarding the mandatory due process guarantees in the statutory frameworks governing arbitration, which generally reflect those guarantees of ECHR Article 6 which the parties do not waive by entering into the arbitration agreement. In mediation, national courts can also play a role in safeguarding certain due process requirements, including ensuring that the mediator has not unduly influenced the mediated settlement.

The analyses also show that courts play an important role in safeguarding rules of public policy (ordre public) in all three types of civil dispute resolution. The concept of 'public policy' traditionally comprises the most fundamental public values and interests in a society; at the same time, however, it remains a flexible legal concept that can take into consideration important developments in society as well as in the law. Arguably, courts should take a consistent approach to defining the concept of 'public policy' (ordre public) across all three types of civil dispute resolution, which should take into consideration the significant developments mentioned in Sect. 1 above. The scope of the concept of 'public policy' can be crucial in defining the reach of state legal orders vis-a-vis private legal orders in our currently globalised world. ${ }^{76}$

With regard to mandatory statutory protection laws, which do not fall within the concept of public policy (ordre public), the analyses show significant differences across the three types of civil dispute resolution. In civil litigation, courts can play an active role in safeguarding such mandatory statutory protection, particularly through judicial guidance of self-represented parties. In many cases, however, Nordic courts have no duty, but a wide discretion, to take on such an active role. In some cases raising issues of EU law, courts must use this discretion to safeguard, for example,

${ }^{76}$ See Hansen et al (2020). 
consumer protection. In these regards, the de facto public policy-implementing role of courts in civil litigation is generally fragmented and unclear. In arbitration, the Nordic arbitration acts provide significant protection of certain public values and interests (in particular, consumer protection laws) through the restrictions mentioned in Sect. 3.2.1 above. Outside the scope of these restrictions, national courts generally cannot safeguard mandatory statutory protection laws in arbitration, unless they fall within the concept of public policy (ordre public). The same is true in the case of mediation. The analyses thus show that the choice of civil dispute resolution can significantly affect the legal effects of such mandatory statutory protection laws. The increasing focus on arbitration and mediation as alternatives to civil litigation makes it pertinent to consider the potential for developing a more consistent approach to the public policy-implementing role of courts in all three types of civil dispute resolution.

With regard to other rules of law, the role of courts in safeguarding any public values and interests associated with such laws is generally limited. In civil litigation, courts may have a duty to provide judicial guidance, particularly to self-represented parties. Apart from such explicit duties, courts generally have a wide discretion, but no duty, to give hints and feedback to the parties, and such rules of law generally do not limit their competence to promote settlement. In arbitration and mediation, courts generally cannot play a public policy-implementing role with regard to such other rules of law.

The societal developments mentioned in Sect. 1 above make it relevant to consider developing a clearer and more consistent approach to defining the public policyimplementing role of courts across all three types of civil dispute resolution. This will require further analyses of the legal frameworks and concepts mentioned above in light of the relevant public values and interests. Since the Nordic countries generally share many of these relevant public values and interests, it will arguably be valuable to analyse this public policy-implementing role of courts in a Nordic context. This represents an important task for future Nordic legal research in this area.

\section{References}

Adrian L (2016) The role of the court-connected mediation and judicial settlement efforts in the preparatory stage. In: Ervo L, Nylund A (eds) Current trends in preparatory proceedings. A comparative study of Nordic and former communist countries. Springer, Cham

Adrian L, Bager S, Petersen CS (2015) Perspektiver på forligsmægling. Juristen 3:98-106

Bang-Pedersen UR, Christiansen LH, Petersen CS (2017) Den civile retspleje. Pejus, Copenhagen

Brooker P (2013) Mediation Law: Journey through Institutionalism to juridification. Routledge, Oxfordshire

Christensen LH (2008) Rettens prøvelse i udeblivelsessager - særligt i forbrugerforhold. Erhvervsjuridisk Tidsskrift 2:129-144

Cordero-Moss G (1999) International Commercial Arbitration: Party Autonomy and Mandatory Rules. Tano Aschehoug, Oslo

Cordero-Moss G (2018) Norsk ordre public som skranke for partsautonomi i internasjonale kontrakter og internasjonal tvisteløsning. Universitetsforlaget, Oslo 
Cuniberti G (2015) Rethinking international commercial arbitration: towards default arbitration. Edward Elgar Publishing, Cheltenham

Deloitte (2013) Analyse af civile sager. Deloitte

Ekelöf PO, Edelstam H (2002) Rättegång. Första häftet. Norstedts Juridik, Stockholm

Eldjarn E (2016) Materiell prosessledelse. Cappelen Damm Akademisk, Oslo

Faldborg A, Troelsen K (2016) Sort arbejde - kan det betale sig? Erhvervsjuridisk Tidsskrift 3:200

Genn DH (2012) Why the privatization of civil justice is a rule of law issue, 36th F A Mann Lecture, Lincoln's Inn. https://www.ucl.ac.uk/laws/sites/laws/files/36th-f-a-mann-lecture-19.11. 12-professor-hazel-genn.pdf

Hansen et al (2020) Private governance and the potential of private law. Eur Rev Private Law 2-2020:333-374

Hess B, Pfeiffer T (2011) Interpretation of the public policy exception as referred to in EU instruments of private international and procedural law. PE 453.189. European Parliament, Brussels

Hess B (2019) Privatizing dispute resolution and its limits. In: Loïc Cadiet et al (eds) Privatizing dispute resolution: trends and limits. Nomos, Baden-Baden, pp 17-46

Hess B, Law S (2019) Implementing EU consumer rights by national procedural law. Luxembourg Report on European Procedural Law Volume II. Beck/Hart/Nomos

Implement Consulting Group (2015) Analyse af rets- og forligsmægling. Implement Consulting Group

Jaksic A (2002) Arbitration and human rights. Peter Lang, Bern

Jaksic A (2007) Procedural guarantees of human rights in arbitration proceedings: a still unsettled problem? J Int Arbitr 24:159-171

Juul J, Thommesen PF (2017) Voldgiftsret. Karnov Group, Copenhagen

Krumins T (2019) Arbitration and human rights-lack of setting-aside proceedings as a violation of the ECHR (PhD Thesis, University of Copenhagen 2019). University of Copenhagen, Copenhagen

Lenaerts K, Maselis I, Gutman K (2014) EU procedural law. Oxford University Press, Oxford

Lindell B (2012) Civilprocessen. Iustus Förlag, Uppsala

Lindskog S (2012) Skiljeförfarande: en kommentar. Norstedts Juridik, Stockholm

Murray PL, Stürner R (2004) German civil justice. Caroline Academic Press, Durham, North Carolina

Petersen CS (2014) A Comparative perspective on recent Nordic reforms of civil justice. In: Ervo L, Nylund A (eds) The Future of Civil Litigation. Springer, Cham, pp 9-29

Petersen CS (2019) Den civile retspleje under forandring. In: Ulrik Rammeskow Bang-Pedersen et al. (eds) Retsplejeloven 100 år. DJØF Forlag, Copenhagen

Petersen JH (2019) Nordic models of welfare states. In: Letto-Vanamo P et al (eds) Nordic Law in European Context. Springer, Cham, pp 21-39

Rosenmeier HP (1984) Nogle aktuelle spørgsmål ved retternes behandling af borgerlige sager, hvor sagsøgte udebliver. Advokaten 7:117-120

Schei T et al (2009) Tvisteloven: Kommentarutgave Bind I. Universitetsforlaget, Oslo

Skoghøy JEA (2017) Tvisteløsning. Universitetsforlaget, Oslo

Taksøe-Jensen F (1979) Materiel procesledelse i borgerlige sager. Juristforbundets forlag, København

Tromborg NW (2015) Aftaler i strid med loven - en analyse af de senere års praksis. Erhvervsjuridisk Tidsskrift 4:261-268

Trstenjak V (2013) Procedural Aspects of European Consumer Protection Law and the Case Law of the CJEU. European Review of Private Law 2:451-478

Van Rhee CH (2005) Introduction. In: van Rhee CH (ed) European Traditions in Civil Procedure. Intersentia, Cambridge, pp 3-22

Voldgiftsinstituttet (2018) Behovet for en lov om mediation. Voldgiftsinstituttet

Werlauff E (2008) Privat voldgift med offentligretlige delspørgsmål. Ugeskrift for Retsvæsen 19:152-159 
Werlauff E (2009) Private Arbitration of Incidental Public Law Issues. European Business Law Review 4:565-577

Westberg P (1988) Domstols officialprövning. En civilprocessuell studie i anslutning till RB 17:3 p 1. Juristförlaget i Lund, Lund

Woxholth G (2013) Voldgift. Gyldendal juridisk, Oslo

Zahle H (1983) Udeblivelsesdomme. Om parternes udeblivelse i civile dispositive retssager. Juristforbundets Forlag, København

Open Access This chapter is licensed under the terms of the Creative Commons Attribution 4.0 International License (http://creativecommons.org/licenses/by/4.0/), which permits use, sharing, adaptation, distribution and reproduction in any medium or format, as long as you give appropriate credit to the original author(s) and the source, provide a link to the Creative Commons license and indicate if changes were made.

The images or other third party material in this chapter are included in the chapter's Creative Commons license, unless indicated otherwise in a credit line to the material. If material is not included in the chapter's Creative Commons license and your intended use is not permitted by statutory regulation or exceeds the permitted use, you will need to obtain permission directly from the copyright holder. 